Evangelical poverty, core teaching in the life and spirituality of Venerable Aloysius Schwartz, priest and founder

Candiasan, Mark Ceasar

Theology and Religious Education Department, De La Salle University - Manila, Philippines (mark_ceasar_candiasan@dlsu.edu.ph)

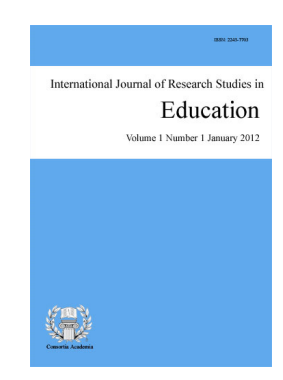

Del Castillo, Fides $\$

Theology and Religious Education Department, De La Salle University - Manila, Philippines (fides.delcastillo@dlsu.edu.ph)

ISSN: $2243-7703$ Online ISSN: 2243-7711

OPEN ACCESS

\title{
Abstract
}

Evangelical poverty is a core element in the teaching and spirituality of Aloysius Schwartz, priest and founder of the Sisters of Mary and Brothers of Christ. As a member of this institute, there is a need to explore his important ideas on poverty in order to assimilate better his teachings and for readers to understand his message for the world as a spiritual leader and teacher. He himself had practiced what he taught and became a living example of this poverty. The purpose of this research therefore, is to investigate how Aloysius Schwartz understood and taught evangelical poverty based on his writings and heroic life of witness. Using a crosssectional reading of various works written by Aloysius Schwartz, this study presented his main ideas, thoughts and understanding on what evangelical poverty is all about. Reading the various works of Aloysius Schwartz on evangelical poverty, one can understand how he conceived and defined poverty. For him, evangelical poverty is an encounter with Christ, imitation of Christ and overcoming suffering in union with Christ on the cross. This study definitively answers the question regarding the understanding and thoughts of Aloysius Schwartz on evangelical poverty. Further studies are needed to establish the importance of this ideas and understanding to Catholic theology and spirituality to understand the theological ideas behind his spirituality on poverty.

Keywords: Christ-consciousness; Christ-possession; poverty; sacrament of the poor; self-transformation; spirituality 


\section{Evangelical poverty, core teaching in the life and spirituality of Venerable Aloysius Schwartz, priest and founder}

\section{Introduction}

Evangelical poverty is an encounter with Christ, an imitation of Christ, and the overcoming of suffering in union with Christ on the cross (Schwartz, 1991). The Report of the Theological Commission on his cause for Beatification and Canonization (2004) mentioned that his major theme of writings is Christian poverty and service to the poor. The two-fold theme encompasses the spirit and praxis of his intimate relationship, commitment, and identification with Jesus (Congregatio de Causis Sanctorum, 2012). Schwartz's life was marked with total poverty as various witnesses testify that he lived it to the full, even to the extreme. Importantly, his life of poverty was an imitation of Christ, poverty of fact, and spirit in moderation, a preferential option for the poor, and the dependence and limitation in the use and disposition of goods (Congregatio de Causis Sanctorum, 2012).

\subsection{Knowing Venerable Aloysius Schwartz}

Aloysius Philip Schwartz (1930-1992) is an American Roman Catholic priest from Washington D.C., U.S.A., who founded the World Villages for Children in South Korea, Philippines, Mexico and some countries in the Central and South America. Along with it, he also founded the congregations of the Sisters of Mary and the Brothers of Christ. He received prestigious awards such as the Ramon Magsaysay Award for International Understanding in 1983 and the Mother Teresa Award in 1988. In 1989, he was diagnosed to have Amyotrophic Lateral Sclerosis or ALS, a terminal illness that took his life on March 16, 1992 (Ranada, 2006). On May 24, 2004, the Archdiocesan Process for the Cause of his Beatification and Canonization was concluded at Silang, Cavite. On January 23, 2015, His Holiness Pope Francis declared Aloysius Philip Schwartz a man of heroic virtues, thus, endowing him the title Venerable. The cause for his beatification and canonization for sainthood is still going on. At present, an authentic miracle through his intercession is needed for him to be elevated as Blessed in the Catholic Church (Fr. Al's Commission Office, 2016).

Evangelical poverty is a core element in the teaching and spirituality of Aloysius Schwartz. He taught the importance of evangelical poverty as an imitation of Christ the poor beggar. Evangelical poverty for him is a deliberate and voluntary choice done in faith to follow Jesus Christ. This spirituality is finding God in the poor, the lowly and ordinary ways (Cueto \& del Castillo, 2017; Cueto, del Castillo, \& Lago, 2019; Hirang, 2020). Although evangelical poverty is a frequent topic, a definite understanding and interpretation of how he conceived evangelical poverty is not available or adequately explained. This research aims to answer how Schwartz understands evangelical poverty. Why does he mean evangelical poverty is an encounter, imitation, and overcoming of suffering? Through cross-sectional reading and examining his various works on evangelical poverty along with various interpretations of it, the researcher aims to define his thoughts, ideas, and main points on evangelical poverty.

This research aims to explain and supplement the spiritual thoughts, main ideas, and points of Aloysius Schwartz on evangelical poverty as the religious and spiritual founder of the congregations of the Sisters of Mary and Brothers of Christ. The research is also taken from the various commentaries done on his works mainly by the theologians Romulo-Jesus Rańada and Felix Podimattam. Another valuable source is the Positio of Aloysius Schwartz which was published by the Congregation for Causes of Saints which analyzed and approved his writings as well as his heroic life of witness. As conceived in this research, evangelical poverty according to Aloysius Schwartz is an encounter with Christ, imitation of Christ, and union in the suffering of Jesus on the cross.

12 Consortia Academia Publishing (A partner of Network of Professional Researchers and Educators) 


\section{Evangelical poverty}

Evangelical poverty is an encounter with Christ as Aloysius Schwartz wrote and constantly preached. For him, the Christian God is a God of encounters, a hidden God who is humble (Schwartz, 1991). Writing on this idea of Schwartz, the theologian Felix Podimattam wrote:

Christ lives on in the world today and exerts his influence upon it primarily in four distinct ways, the Eucharist, Sacred Scripture, the Magisterium of the Church, and the person of the poor... his living presence in the Bread, the Book, the Church, and the Poor (Podimattam, 2006).

In the book Poverty: Sign of our Times, which Schwartz himself wrote, this message was made clear. As Rańada (2006) explains

"Al Schwartz makes an argument for poverty as precisely as a sign to be read and acted upon by the Church of this generation in obedience to the will of God [...] It is not simply poverty as such but rather, the twofold virtue of material poverty and service of the poor" (p. 197).

\subsection{Christ is present in the poverty of the Bread-Eucharist}

The presence of Christ in the poverty of the Bread according to Schwartz (1966) in his book The Starved and the Silent: The Dramatic Encounter of an American Priest with Christ's Poor in Korea is possible because God chooses to reveal himself through the most finite things in the commonplace, everyday elements of bread and wine and the simple words of human language. In his own words, Schwartz (1991) further explained this in his book To Live is Christ,

"Jesus deliberately chose to be born poor, to live poor, and to die poor. What is more, he comes to us today in the Sacrament of the Eucharist as a poor man. He chooses to hide his power and glory behind the appearance of a little piece of bread which is so insignificant and, in a sense, poor" (p. 45).

Comparing it to the presence of Christ in the poor person, this presence in the Bread is unique as Schwartz (1991) explained,

"Christ speaks of his presence in the poor and his identification with the poor on language remarkably similar to that which he used when he instituted the Sacrament of the Eucharist” (p. 26).

At the same time, Schwartz (1966) also adds,

"Of course Christ is not present in the poor in the same manner by which he is present in the Eucharist... but it does require the same faith to believe in this presence” (p. 158).

With this in mind, Podimattam (2006) commented on this idea of Schwartz,

"The presence of Christ in the poor marvelously complements his presence in the Eucharist. In the Sacrament of the Eucharist, the Son of God gives himself to us in the form of the bread...In the sacrament of poverty [the presence of Christ in the poor as Schwartz calls it], Christ is now the beggar, and he humbly approaches us and pleads for bread" (p. 115).

All of this is possible as Rańada (2006) commented to this idea of Schwartz,

"God chooses to hide his glory and power in the humblest of forms or the lowliest of substances” (p. 26). 


\subsection{Christ is present in the Sacred Scriptures}

In reading the Christian Sacred Scriptures, a Christian will encounter Christ and the poverty of Christ. With this in mind, Schwartz (1991) explained,

"Jesus is also present in the inspired word of scripture. He speaks to our hearts through the divinely inspired words of the Bible. Jesus lives in the book" (p. 16).

This presence of Christ in the Book is unique because the words of God contain divine strength, power, and energy (Schwartz, 1991). He further explained that these words whenever read and meditated with faith and love will enter the heart, touch the soul, and fill the being with its strength (Schwartz, 1991). To illustrate this power, Schwartz cited the experiences of St. Anthony of Egypt and St. Francis of Assisi who walked the way of total renunciation and abject poverty upon hearing and encountering the word of God.

Schwartz (1991) wrote,

"What is more important, whenever we read it with faith and meditate upon it with love, we come into intimate personal contact with the living Christ. His heart speaks to my heart and these two hearts become one" (p. 23).

Podimattam (2006) commenting on this idea of Schwartz explained,

"[In the Scriptures] the prophets were inspired to associate themselves especially with the poor. Their mission was twofold, (1) to announce the word of God to the children of men, and (2) to defend the rights of the poor in the face of unjust aggressors" (p. 112).

Similarly, Rańada (2006) wrote,

"In the end, the importance of the Scriptures, for Msgr. Al lies not so much in finding joy, consolation, and strength in the word of God, but in experiencing the encounter one could have with Christ" (p. 26).

\subsection{Christ is present in the poor, known as the "sacrament of the poor"}

What Schwartz means in the sacrament of the poor is the divine indwelling of Christ among the poor as a sign of his presence in the world. He is not referring to the seven Sacraments of the Church such as the Holy Eucharist. Explaining this reality in his Positio, one can read,

"From his first-hand and prayerful experience of the poor and poverty in Korea, he propounds a somewhat theological mystical view of poverty as a sacrament, that is, a natural sacrament, an outward sign of inward grace... of humility and lowliness (Congregatio de Causis Sanctorum, 2012, p. 657).

In the words of Schwartz (1991) himself, he explained,

"In the twenty-fifth chapter of St. Matthew, Christ in a similar manner institutes what may be described as the sacrament of the poor... [This he means when he refers to the following:] Amen, amen I say to you, as long as you did it to one of these, the very least of my brothers, you did it to $m e "$ (p. 26).

He further explained,

"The poor were now imbued not only with a new dignity, value, and glory, but the poor- in a sense- became Christ himself...Christ not only gives the poor priority, but he also identifies with the poor and becomes one with them. Henceforth, whatever you do to the poor, you do to

14 Consortia Academia Publishing (A partner of Network of Professional Researchers and Educators) 
Christ ...you are in effect entering into direct, intimate contact with the living Christ" (pp. 26-27).

In another book, Schwartz (1966) wrote,

"In the sacrament of poverty, Christ is now the beggar, and he humbly approaches us and pleads with us to give him the bread...They have been anointed by poverty and suffering to become mediators between man and God. Through them, men are permitted to sacrifice themselves to God, and in turn, God gives himself to men" (p. 161).

Rańada (2006) commenting on Schwartz, wrote,

"According to Msgr. Al, God has always been consistent, even up to the present, in his humble manifestation of himself in the poor" (p. 27).

With this in mind, it is clear that Schwartz emphasized the importance of the words of Jesus who proclaimed his presence among the least. Thus, Rańada (2006) further explained,

In short, encountering the poor is encountering Christ. The poor is the sacrament of Christ; the sign and instrument of his venerable presence. And although he would only put it in lower case and between quotation marks "sacrament of the poor" in order, perhaps, not to place it at par or confuse it with the Sacraments of the Church, Msgr. Al does not hesitate to compare the significance of this "sacrament" as well as its demands with that of the Sacrament, particularly the Eucharist and Reconciliation (p. 29).

Christian holiness is the imitation of Christ. It is because Christ is the image of God among men and the perfect human image God wants men to become (Ranada, 2006). To illustrate this, Schwartz developed the idea of self-transformation into Christ-consciousness and Christ-possession.

\subsection{Evangelical poverty is total self-transformation into Christ-Consciousness or Christ-centeredness}

For Schwartz (1991), Christ- Consciousness or Christ-centeredness simply means to serve the poor with the mind, heart, and spirit of Christ. To illustrate this, he wrote,

"Paul in a sense, rid himself of all self-consciousness and replace it with Christ- consciousness. Paul was more aware of Christ than he was to himself. Christ was more real to him than Paul to himself. Paul lived for Christ, and Christ alone" (Schwartz, 1991, p. 2).

Furthermore, he continued,

"In this spiritual surrender to Christ...It permits you to get out of yourself and away from yourself. You are lost in Christ-consciousness...To lose one's life for Christ's sake means to renounce self, to die to self, to get away from self, to be indifferent to self, and to seek Christ and Christ alone" (pp. 2-3).

For him, this Christ-consciousness is expressed in the service to the poor that reveals the meaning of the identity of the mission of Jesus who is God with us, not apart, separated or withdrawn (Schwartz, 1991). Rańada (2006) made clear that what Schwartz meant here is the transformation of the person into Christ and the conformation into this image. Thus, he wrote,

"It is the transformation involving a radical shift in one's consciousness, namely, from self-consciousness to Christ-consciousness. This means an awareness of Christ that is so acute or so sharp that one's awareness of oneself pales in comparison. It involves, as it were, a forgetfulness of oneself and a concomitant attention given solely and fully to Christ" (p. 9). 
Christ-possession for Schwartz simply means the deepening of a personal relationship with Jesus and the discovery of this love towards the person. This realization is best expressed in his words,

"He [God] loves me more than I love myself" (Schwartz, 1991, p. 4).

For him, it is a certain presence within a heart, the force, and the love that is below, above, behind and surrounds the person (Schwartz, 1991). Furthermore, it is a mystical experience that is ineffably sweet, gentle, and delightful as opposed to demonic possession found in the gospels. Schwartz (1991) explained,

"The union of the soul with Christ is not simply one of flesh and blood-it is a union of hearts, the oneness of spirits, a melding of souls" (p. 3).

Rańada (2006) commented on this idea,

"Msgr. Al thus speaks of what he calls Christ-possession. In explaining Christ-possession, he speaks of the loss of personal freedom and the taking over of one's will, or one's center and source of action, by that of another" (p. 10).

Thus, Rańada (2006) simply wrote that this Christ- possession means the ecstasy of love, communion, and friendship with Jesus. To illustrate this, Bayer (2019) wrote,

To search for God, we must first be free for him (vaca deo). Everything else must be set aside. To find what is absolute, we must first be able to acknowledge that all else is relative. What we cannot lay down holds our hearts hostage and inhibits us from searching for God. It has taken his place. Interior freedom is necessary to find God...Only in this way can the heart find the coherence and wholeness (totum cor meum) necessary to search for God (p. 3).

One can associate what Bayer argues that Christ's possession is the total availability of the person to God. He argues that it is the discovery of the freedom for the pure of heart that bestows life in the vision of God (Bayer, 2019). Thus Bayer (2019) explained,

"The world needs men and women who are ready to give themselves away totally and in this way to testify to the reality of God. If we are honest with ourselves, we long to unify our lives under a single absolute, and yet no one other than God is worthy of a total commitment. How precious it is that we can root ourselves existentially in what is absolute... (p. 13).

\section{Evangelical poverty in union with Jesus on the Cross}

The suffering and degradation of the poor through material poverty is seen by Schwartz (1966) in the image of Jesus on the cross. On this account, he wrote,

"They, too, are starved and silent, spiritually and physically. They, too, are silent. Like the poor everywhere and in every time, they lack the power and authority that accompany wealth; therefore, they are unable to cry out and arouse a sleeping world" (p. 7).

Furthermore, Schwartz (1991) explained, "Real poverty hurts. It causes pain and requires sacrifice. St. Francis de Sales writes,

'Many would like to have the reputation of being poor, and that at the same time live comfortably and pleasantly.' This is mere pious play-acting and is far removed from the practical poverty which Jesus holds as an ideal to his disciples" (pp. 51-52).

This mark of the cross by Jesus is therefore not unknown to him as Schwartz (1991) wrote,

16 Consortia Academia Publishing (A partner of Network of Professional Researchers and Educators) 
"Jesus, by deliberate choice, was born poor, lived poor, and finally he died poor... He empties himself, gives all that he has to give, and dies in absolute nothingness and poverty" (p. 49).

He further explained,

"Jesus deliberately chooses what is lowly rather lofty; what is insecure rather secure, what is uncomfortable rather than what is comfortable; what is poor rather than what is rich. This pattern continues throughout the life of Jesus" (p. 46).

Commenting on this idea of Schwartz, Rańada (2006) wrote,

"It is clear that Christ cannot be understood well without the cross. His image is essentially attached to it just as much as the image of the Servant of God in the Book of the Prophet Isaiah is attached to suffering and is understood in relation to it" (p. 115).

\section{Venerable Aloysius Schwartz suffered missionary discomforts, trials, and ALS}

In the life of Aloysius Schwartz, it is known that he suffered as a missionary with various discomforts until his death. For him, this suffering was a union with Christ on the poor, in total poverty. To illustrate this, Schwartz (2011) explained his situation in his autobiography,

"[The song Killing me Softly with Her Song] aptly describes the disease with which I am now afflicted. It is called Lou Gehrig's disease. It is a terminal illness which kills me but ever so slowly, ever so cruelly, ever so softly" (p. 1).

In his letter to a certain nun dated May 12, 1989, he gave a hint to his suffering by writing,

"I continue to enjoy poor health. But Jesus always gives me enough strength to do what he wants me to do... So I try to glory in my weakness and continue to praise the Lord for his marvelous ways" (Fr Al's Commission Office, 2016, p. 155).

With this strength and courage, Schwartz (1991) explained,

"To follow Jesus [especially in his poverty] means the cross. And the cross means suffering, pain, humiliation, and death. It is not something romantic, sentimental, nor philosophical. Suffering is not a game. Pain is not a child's play. And death is no laughing matter" (p. 108).

Knowing what suffering and pain are, Schwartz understood the poverty of the cross by saying,

"The cross is not just physical pain but total annihilation, complete humiliation. The cross is an experience of one's weakness and powerlessness and I must submit myself to this; yet, Jesus gets up and goes forward...He gives us the strength, the power, the grace to endure it, and to move forward" (Fr. Al's Children Foundation, 2018, p.74).

Furthermore, he said,

"If I have the mind and heart of Christ Jesus, I, too, must constantly choose what is poor rather rich, what is lowly rather than what is lofty, what gives pain and discomfort rather than what gives pleasure and comfort. I must believe in the cross, love the cross, choose the cross and carry the cross daily" (Fr, Al's Children Foundation, 2018, p. 72).

His understanding of suffering is unique as he wrote in his autobiography,

"Suffering is the supreme test of faith, confidence, and trust in God" (Schwartz, 2011, p. 124).

Moreover, he added, 
"I believe this suffering, humiliation or pain I endure is purposeful, is fruitful and productive... He loves us so much that he wants us to participate in the greatest...work imaginable which is the saving of souls...In this spirit, St. Paul writes, I make up in my body the sufferings what is lacking in the body of Christ" (Schwartz, 2011, p. 119).

To sum up, Rańada (2006) made his remark on this condition of Schwartz,

"Msgr. Al knows what he is talking about. Even before he came to face the greatest trial of his life which was the disease ALS, his idea of God giving us only grace enough for the trial we are facing was already present in many of his writings" (p. 124).

\section{Conclusion}

Poverty is a multidimensional phenomenon that is often measured based on income and consumption (Chudasama \& Singh, 2014). It encompasses the economic, social, and psychological aspects of the human condition. It affects the life of every human being since it is the most enduring social and cultural phenomena in the world. However, Aloysius Schwarts taught Christian faithful that poverty can be alleviating. It is a great opportunity to encounter Christ in every facet of suffering. The experience of poverty is also a time to imitate the examples of Christ. Thus, allowing humans to overcome suffering and be transformed into the image and likeness of Christ.

\section{References}

Bayer, J. (2019). Living toto corde: Monastic vows and knowledge of God. Religion, 10(7). https://doi.org/10.3390/rel10070424

Congregatio de Causis Sanctorum. (2012). Manilensis beatification and canonization of the Servant of God Louis Schwartz, a priest of the diocese, founder of Mary and his brothers and sisters in Christ (19301992): The position on the life, virtues and reputation of sanctity [Manilensis Beatificationis et Canonizationis Servi Dei Aloisii Schwartz, Sacerdotis Diocesani, Fundatoris Congregationum Sororum Mariae et Fratrum Christi (1930- 1992): Positio Super Vita, Virtutibus et Fama Sanctitatis]. Rome: Tipografia Nova Res.

Cueto, A., \& del Castillo, F. (2017). Finding god in the ordinary: Exposition of the little flower' spirituality. Asia Pacific Journal of Multidisciplinary Research, 5(1), 160-174.

Cueto, A., del Castillo, F., \& Lago J. (2019). Perspectives on kabanalan (holiness) among Filipino young professionals: Implications in theology and catholic education. Asia Pacific Journal of Multidisciplinary Research, 7(4), 1-11.

Fr. Al's Children Foundation. (2016). In the joy of the Lord: Compilation of Fr. Al's letters to Sr. Gertrude, OCD (1978-1990). Cavite: The Sisters of Mary.

Fr. Al's Children Foundation. (2018). Handbook of prayers. Cavite: The Sisters of Mary.

Hirang, L., \& del Castillo, F. (2020). Marian spirituality: The experience of legionaries in the Philippines. Asia Pacific Journal of Multidisciplinary Research, 8(2), 41-45.

Podimattam, F. (2006). Consecrated poverty: Revisited. Delhi: Media House.

Rańada, J.-R. (2006). A heart for the poor: The thought and spirituality of Msgr. Aloysius Schwartz. Quezon City: Claretian Publications.

Schwartz, A. (1966). The starved and the silent: The dramatic encounter of an American priest with Christ's poor in Korea. London, UK: Doubleday.

Schwartz, A. (1991). To live is Christ: The sisters of Mary book of spirituality. Rockville: Government Institutes, Inc.

Schwartz, A. (2011). Killing me softly: The inspiring story of a champion of the poor. New York, NY: Alba House. 